\title{
Source identification of nitrate by means of isotopic tracers in the Baltic Sea catchments
}

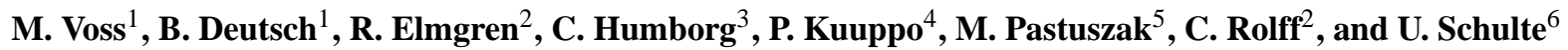 \\ ${ }^{1}$ Baltic Sea Research Institute, Seestr. 15, 18119 Rostock, Germany \\ ${ }^{2}$ Stockholm University, Department of Systems Ecology, 10691 Stockholm, Sweden \\ ${ }^{3}$ Stockholm University, Department of Applied Environmental Science, 10691 Stockholm, Sweden \\ ${ }^{4}$ Finnish Environment Institute, P.O. Box 140, 00251 Helsinki, Finland \\ ${ }^{5}$ Sea Fisheries Institute, Kołłątaja 1, 81-332 Gdynia, Poland \\ ${ }^{6}$ Ruhr Universität Bochum, Universitätsstr. 150, 44780 Bochum, Germany
}

Received: 2 March 2006 - Published in Biogeosciences Discuss.: 12 June 2006

Revised: 22 November 2006 - Accepted: 28 November 2006 - Published: 20 December 2006

\begin{abstract}
Nitrate input to a river is largely controlled by land use in its catchment. We compared the information carried by the isotopic signatures of nitrate in 12 Baltic rivers, in relation to the vegetation cover, land use, and fertilization of agricultural land of their catchments. We found isotope values in nitrate ranging from -2 to $14 \%$ for $\delta^{15} \mathrm{~N}$ and 8 to $25 \%$ o for $\delta^{18} \mathrm{O}$. The annual variability of riverine nitrate isotope signatures is presented in detail for one Nordic, the Kemijoki, and two southern rivers, the Vistula and Oder. Nordic rivers with relatively pristine vegetation in their catchments show not only low $\delta^{15} \mathrm{~N}$ values and high $\delta^{18} \mathrm{O}-\mathrm{NO}_{3}^{-}$but also lower annual variability than rivers draining densely populated land. Seasonal signals were found in all the rivers. We used load weighted nitrate isotope data and data from the three major $\mathrm{N}$ sources (farmland/sewage, atmospheric deposition and from runoff of pristine soils) to theoretically estimate the shares of nitrate from these sources. The results of an isotope mixing model (IMM-1) agree reasonably well with the same estimates for agricultural land derived from a Global Land Cover (GLC) data base, with a deviation varying from $-16 \%$ to $+26 \%$. The comparison with an emission model (EM) reveals relatively good agreements for intensively used catchments ( -18 to $+18 \%$ deviation). Rather unsatisfactory agreement was found between the IMM- 1 and GLC calculations for pristine catchments $(-36$ to $+50 \%$ deviation). Advantages and limitations of the tested model are discussed.
\end{abstract}

Correspondence to: $\mathrm{M}$. Voss

(maren.voss@io-warnemuende.de)

\section{Introduction}

Humans create reactive $\mathrm{N}$ at rates that now exceed the natural conversion of atmospheric $\mathrm{N}_{2}$ into combined $\mathrm{N}$ (Galloway et al., 1995). Most of this anthropogenic combined nitrogen is used as fertilizer for human food production and much is unintentionally widely distributed by uncontrolled hydrologic and atmospheric transport (Howarth et al., 1996). In humid climates a considerable fraction of the $\mathrm{N}$ surplus from fields and meadows ends up in rivers. A study of 16 different watersheds along the east coast of the United States showed high variability in nitrogen sources and the proportion exported (Boyer et al., 2002). A large but not well constrained share of that nitrogen $(37-76 \% \mathrm{~N})$ is lost in passage to the sea (Seitzinger et al., 2002) and many coastal areas suffer under the riverine nitrogen load (Galloway and Cowling, 2002).

The nitrogen export as a function of land use can best be studied in well-described catchments like those of the Baltic Sea, a shallow, intra-continental, brackish sea with an area of $400000 \mathrm{~km}^{2}$ and a four times larger drainage basin. Baltic rivers have a combined mean fresh water inflow of $15400 \mathrm{~m}^{3} \mathrm{~s}^{-1}$ (HELCOM, 2002), resulting in salinities around 2 in the northernmost Gulf of Bothnia and still only 7-8 in surface waters of the Baltic Proper, where anoxic conditions below the marked halocline at $60-80 \mathrm{~m}$ depth generally favour phosphate release from sediments. A rapid increase in nitrate concentrations in the central Baltic Sea in the 1970s has been attributed to river nitrogen loading, since catchment fertilizer usage increased drastically in this period (Larsson et al., 1985; Nausch et al., 1999). Recent studies have challenged this view and suggest that much of the

Published by Copernicus GmbH on behalf of the European Geosciences Union. 
river N-load is sequestered and denitrified already near the coast (Voss et al., 2005). But there is still no doubt that the low winter N/P-ratios found in the Baltic Proper favour high combined nitrogen inputs via nitrogen fixing organisms (Elmgren, 2001).

Eutrophication is a major environmental issue in the Baltic Proper, and particularly in its coastal regions, where most of the total nitrogen input is from rivers (Elmgren, 2001). Stålnacke (1999) estimated the input of nitrate from the five largest rivers, Vistula, Daugava, Oder, Neva, and Nemunas, for the period 1983-1999 to $183 \mathrm{kt} \mathrm{yr}^{-1}$ of nitrogen, about half of the total annual riverine nitrate delivery to the Baltic. These rivers enter the Baltic Sea in the south and east, and - except for Neva - all drain densely populated agricultural areas. A relationship between fertilizer use in the catchments and the river load supports this conclusion (Nausch et al., 1999). Agriculture is thus a major source of riverine nitrate, to which is added sewage from urban areas and industries (e.g. paper industries). Atmospheric deposition is the second largest diffuse nitrate source for the Baltic Sea and it is less well constrained than the river load (Granat, 2001; Grimvall and Stålnacke, 2001).

The stable isotope signatures of nitrogen $\left(\delta^{15} \mathrm{~N}-\mathrm{NO}_{3}^{-}\right)$and oxygen $\left(\delta^{18} \mathrm{O}-\mathrm{NO}_{3}^{-}\right)$have been used successfully in the past to attribute nitrate in river water to specific sources. For instance, nitrate in streams during early snowmelt was shown to originate from pre-melt periods and not from the nitrate deposited in winter (Kendall, 1998; Kendall et al., 1995). A comparison of 16 watersheds in the U.S. corroborated the hypothesis that the isotopic signature of nitrate differs between forested catchments and agricultural land (Mayer et al., 2002). The reasons for such differences in $\mathrm{N}$ and $\mathrm{O}$ isotope ratios in nitrate are both the ultimate sources of $\mathrm{N}$ and $\mathrm{O}$, and kinetic fractionation processes which tend to partition light isotopes $\left({ }^{14} \mathrm{~N}\right.$ and $\left.{ }^{16} \mathrm{O}\right)$ from heavier ones $\left({ }^{15} \mathrm{~N}\right.$ and ${ }^{18} \mathrm{O}$, Kendall, 1998; Mariotti et al., 1984). Nitrate produced by the Haber-Bosch-process has isotope ratios close to atmospheric values for both $\mathrm{N}(0 \%$ ) and $\mathrm{O}(23.5 \%$, Amberger and Schmidt, 1987). When soil organic matter is degraded and nitrified, the resulting nitrate $\delta^{15} \mathrm{~N}$ decreases, while the $\delta^{18} \mathrm{O}$ value depends on the source of water (Mayer et al., 2001). Denitrification generally leads to isotope values increasing at a 2:1 ratio for $\delta^{15} \mathrm{~N}$ and $\delta^{18} \mathrm{O}$ values, but deviations from this ratio due to temperature variability and substrate concentration have been observed (Böttcher et al., 1990). If substrate limitation leads to total conversion of nitrate to dinitrogen gas there is no apparent fractionation (Brandes and Devol, 1997). The highest $\delta^{18} \mathrm{O}$ values are found in nitrate from atmospheric deposition (Kendall, 1998; Kendall et al., 1995), while the highest $\delta^{15} \mathrm{~N}$ values have been measured in manure and septic tanks, where ${ }^{14} \mathrm{~N}$ is preferentially lost via ammonia volatilisation (Heaton, 1986). The ranges of isotope values for different sources tend to overlap, but even then measurements of both stable isotope pairs can often give a unique characterization of nitrate from different sources (Kendall, 1998).

The Baltic Sea catchment is especially suitable for comparing nitrate sources in rivers, since northern rivers drain near-pristine catchments, while southern ones have densely populated watersheds with much agriculture. The present study was presented at the Conference on "Significant Processes, Observations and Transformation of Ocean Nitrogen" (SPOT-ON) as an example of human influence on the catchment scale. We use dual-isotope data for nitrate as a tool for determining nitrate sources in river systems, while also evaluating seasonal changes in isotopic values. Additionally, nitrate source attributions by isotope mixing models and an emission model are tested. We demonstrate the basic feasibility and practical limitations of such studies for the characterization of catchments, and establish rough relationships between land use and isotopic signatures.

\section{Material and methods}

\subsection{River sampling and isotopic analysis}

River water was sampled monthly for 2 years (July 2000 to June 2002), except biweekly in the Vistula and Oder, and approximately bimonthly in the Neva. Samples were taken with a bucket at the official HELCOM river monitoring sites, which are located some $20-30 \mathrm{~km}$ upstream of the river mouth $(100 \mathrm{~km}$ in the Oder). Water samples were processed in the laboratory within hours of sampling. Nitrate, nitrite, ammonia, and phosphate were measured following standard protocols (Grasshoff et al., 1983), while total nitrogen and phosphorus were determined through simultaneous persulphate oxidation of $\mathrm{N}$ and $\mathrm{P}$ (UNESCO, 1983). Not all variables were always measured for all rivers (Table 1). A water sample of $0.5-1 \mathrm{~L}$ was filtered through precombusted $\mathrm{GF} / \mathrm{F}$ filters, which were then dried, and the filtrate for $\delta^{15} \mathrm{~N}$ $\mathrm{NO}_{3}^{-}$analysis was preserved with $1 \mathrm{ml}$ of concentrated $\mathrm{HCl}$. Also, 0.5-6.0 L was filtered through $0.45 \mu \mathrm{m}$ membrane filters, transferred to a cation exchange resin $(5 \mathrm{ml}$ AG $50 \mathrm{~W}$ $\mathrm{X} 4, \mathrm{H}^{+}$-form; Biorad), followed by collection of at least $60 \mu \mathrm{mol}$ nitrate on an anion exchange resin ( $2 \mathrm{ml}$ AG1-X8, $\mathrm{Cl}^{-}$-form; Biorad), according to Silva et al. (2000). The resin columns were stored cool during transport or in a refrigerator in the laboratory until further preparation at the University of Bochum, where the samples were eluted from the anion exchange resin with $15 \mathrm{ml} \mathrm{3M} \mathrm{HCl}$. Then a solution of $\mathrm{BaCl}_{2} \cdot 2 \mathrm{H}_{2} \mathrm{O}(10 \%)$ was added to remove $\mathrm{SO}_{4}^{2-}$ and $\mathrm{PO}_{4}^{3-}$, precipitated $\mathrm{BaSO}_{4}$ and $\mathrm{Ba}_{3}\left(\mathrm{PO}_{4}\right)_{2}$ being removed by filtration $(0.45 \mu \mathrm{m}$ membrane filter, cellulose-acetate), and the filtrate passed through a cation exchange resin $(5 \mathrm{ml}$ AG $50 \mathrm{~W}-$ $\mathrm{X} 4, \mathrm{H}^{+}$-form; Biorad) to eliminate the excess $\mathrm{Ba}^{2+}$. The filtrate was neutralized with approximately $7 \mathrm{~g} \mathrm{Ag}_{2} \mathrm{O}$ to a pH of 5.5-6, precipitated $\mathrm{AgCl}$ and remaining $\mathrm{Ag}_{2} \mathrm{O}$ was removed by filtration $(0.45 \mu \mathrm{m}$ membrane filter, cellulose-acetate), 
Table 1. Variables measured during the two years of sampling, and used in the PCA analysis. The numbers are the numbers of samples analysed. n.a.= not available.

\begin{tabular}{llllllll}
\hline Variable & Peene & Oder & Vistula & Neva & Paimion-joki & Kokemaen-joki & Kemi-joki \\
\hline $\mathrm{NO}_{3}^{-}$ & 52 & 47 & 48 & $15^{*}$ & $38^{*}$ & $23^{*}$ & $24^{*}$ \\
$\mathrm{NO}_{2}^{-}$ & 52 & 47 & 48 & n.a. & n.a. & n.a. & n.a. \\
$\mathrm{NH}_{4}^{+}$ & 52 & 47 & 46 & 15 & 30 & 22 & 24 \\
$\mathrm{~N}_{\text {tot }}$ & 43 & 46 & 48 & 15 & 33 & 22 & 25 \\
$\mathrm{PO}_{4}^{3-}$ & 52 & 46 & 48 & 15 & 31 & 23 & 25 \\
$\mathrm{P}_{\text {tot }}$ & 43 & 46 & 48 & 15 & 38 & 22 & 25 \\
$\mathrm{DSi}$ & 4 & 47 & 48 & n.a. & n.a. & 7 & 25 \\
$\mathrm{PON}$ & 30 & 47 & 48 & 10 & 19 & 22 & 21 \\
$\mathrm{POC}$ & 9 & 47 & 48 & 10 & 19 & 22 & 21 \\
$\delta^{15} \mathrm{~N}-\mathrm{PON}^{13} \mathrm{C}-\mathrm{POC}$ & 26 & 47 & 47 & 15 & 21 & 22 & 21 \\
$\delta^{15} \mathrm{~N}-\mathrm{NO}_{3}^{-} *$ & 9 & 46 & 47 & 15 & 21 & 22 & 19 \\
$\delta^{18} \mathrm{O}-\mathrm{NO}_{3}^{-}$ & 26 & 47 & 48 & 15 & 24 & 23 & 14 \\
flow rate & 21 & 42 & 44 & 9 & 23 & 20 & 25 \\
\hline
\end{tabular}

* Includes nitrite, which is at most a few percent.

and the solution freeze-dried. Ten $\mathrm{mg}$ of the solid $\mathrm{AgNO}_{3}$ were weighed into quartz tubes together with $2 \mathrm{mg}$ of finely ground pure graphite. For $\delta^{18} \mathrm{O}$ analyses the tubes were evacuated and sealed with a torch. The samples were combusted in a furnace at $850^{\circ} \mathrm{C}$ for about $1 \mathrm{~h}$ and cooled down slowly to room temperature. The resulting $\mathrm{CO}_{2}$ was extracted cryogenically at a vacuum distillation line. The $\delta^{18} \mathrm{O}$ analysis was carried out with a Thermo Delta $\mathrm{S}$ mass spectrometer. The $\delta^{18} \mathrm{O}-\mathrm{NO}_{3}^{-}$values are given in per mil (\%o) relative to Vienna standard mean ocean water (VSMOW) defined as $0 \%$. International reference materials were IAEA-N3 and IAEA-C- 3 where we measured a $\delta^{18} \mathrm{O}$ value of $25.1 \pm 0.6 \%$ o and $32.2 \pm 0.2 \%$, respectively. Precision of the measurement was verified by repeated analysis of an internal laboratory standard $\left(\mathrm{AgNO}_{3}\right)$ with a standard deviation of $1 \sigma=0.38 \%$ o $(n=80)$.

Nitrate- $\delta^{15} \mathrm{~N}$ analyses were carried out with the diffusion method of Sigman et al. (1997). The acidic filtrate samples were brought to a $\mathrm{pH}$ of $10-11$ with $\mathrm{NaOH}$ and $\mathrm{MgO}$ and briefly boiled to remove traces of ammonium from the sample. After 10 days of incubation of the basic solution in an oven $\left(5\right.$ days at $\left.60^{\circ} \mathrm{C}\right)$ and on a shaker table (5 days at $40^{\circ} \mathrm{C}$ ) the acidified filter sandwiched between two Teflon membranes was removed from the incubation flask and dried. Repeated standards from a nitrate solution showed a standard variation of $1 \sigma=0.5 \%$ o $(\mathrm{n}=70)$. All $\delta^{15} \mathrm{~N}^{-\mathrm{NO}_{3}^{-}}$samples were analysed in duplicates and a mean value taken. If the standard variation was $>0.5 \%$ repeated analyses were performed. The GF/F filters from $\delta^{15} \mathrm{~N}-\mathrm{NO}_{3}^{-}$analyses and the $\mathrm{POC/PON}$ filtration were wrapped in tin cups and combusted in an elemental analyser (Thermo 1108) before the gas was measured in a Finnigan Delta S or Delta plus. The calibration substance for the PON and POC analysis was acetanilide. Standard gases were high purity $\mathrm{N}_{2}$ and $\mathrm{CO}_{2}$ gases from $50 \mathrm{~L}$ cylinders calibrated against IAEA standard substances N1 $(0.4 \% o)$, N2 (-20.3\%o), and N3 $(4.7 \%$ ) for nitrogen, NBS$22\left(-29.7 \%\right.$ ) and IAEA-CH6 $\left(-10.8 \%\right.$ o for $\mathrm{CO}_{2}$. As a labinternal standard a protein, peptone (Merck), was run after every fifth sample $\left(\delta^{15} \mathrm{~N} 4.5 \%\right.$ ) . Values are conventionally given in \%o deviation from the standards which were air $\mathrm{N}_{2}$ for nitrogen from $\mathrm{PON}$ and $\mathrm{NO}_{3}^{-}$and V-PDB for $\mathrm{CO}_{2}$ from POC combustion.

The Swedish rivers were analysed for the isotopic composition of total nitrogen only, since nitrate concentrations were usually too low for nitrate $\delta^{15} \mathrm{~N}$ measurements $(<3 \mu \mathrm{M})$. A $500 \mathrm{ml}$ sample of surface water was immediately frozen and transported to the lab. After thawing $300 \mathrm{ml}$ were filtered under pressure through a $25 \mathrm{~mm}$ Whatman $\mathrm{GF} / \mathrm{F}$ glass-fibre filter (precombusted $4 \mathrm{~h}$ at $400^{\circ} \mathrm{C}$ ). The filters were dried for $24 \mathrm{~h}$ at $60^{\circ} \mathrm{C}$ in glass vessels. The filtrate was reduced to $\sim 5 \mathrm{ml}$ at $50^{\circ} \mathrm{C}$ in a vacuum rotavapor (Laborota 4000 ), and freeze dried onto a $25 \mathrm{~mm}$ Whatman GF/F glass-fibre filter (precombusted $4 \mathrm{~h}$ at $400^{\circ} \mathrm{C}$ ). During freeze-drying all liquid containing the dissolved $\mathrm{N}$ is trapped on the glass fibres. Filters were wrapped in ethanol-washed aluminium foil and stored in air-tight plastic containers before being analysed as described above for POC/PON filters.

2.2 Determinations of vegetation cover in catchments and the calculation of $\mathrm{N}$-emissions

Calculations of percentage land cover for each drainage area used ARC VIEW ${ }^{\circledR} 8.1$ and data from the Global Land Cover (GLC) 2000 database (European Commission, Joint Research Centre, 2003; http://www-gem.jrc.it/ 
glc2000). Drainage basin boundaries were also obtained from the Join Research Centre.

The atmospheric $\mathrm{N}$ deposition (wet and dry; reduced and oxidized $\mathrm{N}$ forms) used was obtained from the UNECE/EMEP emission database, which provides annual $\mathrm{N}$ deposition over the Baltic Sea catchment on a sub-catchment scale from 1980 onwards (http://www.mare.su.se/nest/).

$\mathrm{N}$-emissions within the various river catchments from sewage, manure, and mineral fertilizers, each having characteristic $\mathrm{N}$ isotope values, were calculated to compare their shares with the observed isotopic values measured at the river mouths. $\mathrm{N}$ emissions from sewage were calculated from the total population living in a watershed and the connectedness of the total population to primary, secondary and tertiary treatment (EUROSTAT). We assumed that $\mathrm{N}$ emissions per capita are $3.9 \mathrm{~kg} \mathrm{yr}^{-1}$ (Johnes et al., 1996) and reductions in primary, secondary and tertiary treatment is $10 \%, 25 \%$ and $75 \%$, respectively. $\mathrm{N}$ emissions from manure were estimated from livestock data of pigs and cattle in a watershed. $\mathrm{N}$ emissions per diary cows ranged between $50-100 \mathrm{~kg} \mathrm{~N} \mathrm{yr}^{-1}$ as a function of milk production; emissions from other cattle, sows and slaughter pigs were estimated as 34,22 , and $9 \mathrm{~kg}$ $\mathrm{N} \mathrm{yr}^{-1}$, respectively (Claesson and Steineck, 1991). Emissions from mineral fertilizers were taken from FAO statistics (FAOSTAT, 2005), whereas total amounts used per watershed were calculated using Geographical Information Systems (GIS) data on total hectares of arable land that were multiplied by the national average of mineral fertilizer used per hectare in a respective country.

\subsection{River flow rate and load calculation}

Flow rates of the Polish, German, and Finnish rivers were measured continuously at the locations of the hydrological stations (HELCOM, 2004), and the annual and monthly runoffs were calculated using WMO guidelines (World Meteorological Organization, 1994).

Monthly flow rates (given in $\mathrm{m}^{3} \mathrm{~s}^{-1}$ ) were multiplied by the respective concentrations. Annual isotopic data were weighted with the loads, after the formula:

$$
\delta^{15} \mathrm{~N}_{\mathrm{wml}}=\frac{\sum_{i} \delta^{15} \mathrm{~N}_{i} \times \text { concN }_{i} \times \text { flow }_{i}}{\sum_{i} \operatorname{concN}_{i} \times \text { flow }_{i}}
$$

Where $\delta^{15} \mathrm{~N}_{\mathrm{wml}}$ is the load weighted annual isotope value, $\delta^{15} \mathrm{~N}_{i}$ the isotope value for a certain month, conc. $\mathrm{N}_{i}$ is the concentration in $\mu \mathrm{mol}$ and flow $i$ the flow in $\mathrm{m}^{3}$ month $^{-1}$.

\subsection{Isotope mixing models (IMM) and statistics}

For the mixing model calculation we had to restrict ourselves to three sources because nitrate contains only two pairs of stable isotopes. Additional isotope pairs would have been necessary for a finer resolution. The source attribution of the riverine nitrate was made with the Phillips and Koch (2002) isotope mixing program, available at http: //www.epa.gov/wed/pages/models.htm. The basic formulas are:

$\delta^{15} \mathrm{~N}_{R}=f_{F} \delta^{15} \mathrm{~N}_{F}+f_{P} \quad \delta^{15} \mathrm{~N}_{P}+f_{A} \quad \delta^{15} \mathrm{~N}_{A}$

$\delta^{18} \mathrm{O}_{R}=f_{F} \delta^{18} \mathrm{O}_{F}+f_{P} \quad \delta^{18} \mathrm{O}_{P}+f_{A} \quad \delta^{18} \mathrm{O}_{A}$

$1=f_{F}+f_{P}+f_{A}$,

where $\delta^{15} \mathrm{~N}$ and $\delta^{18} \mathrm{O}$ are the nitrate isotope values from the rivers $(\mathrm{R})$, and the three sources for IMM-1, farmland/agricultural land (F), pristine soils (P), and atmospheric deposition (A), while for IMM-2 the sources were sewage/manure $(\mathrm{F})$, mineral fertilizer $(\mathrm{P})$ and atmospheric deposition (A). The sum of all three sources is assumed to be $100 \%$.

Isotopic source data for farmland/agricultural land, and pristine soils for our IMM-1 calculation were taken from a similar study in the German Warnow River (Deutsch et al., 2006) except that for atmospheric deposition in the north (the Kemijoki) we used the data from Burns and Kendall (2002, Table 2). In the IMM-1 calculation we thus distinguish nitrate from agricultural land, from pristine soil runoff, and from atmospheric deposition. The emission model (EM) distinguishes between nitrate from mineral fertilizers and nitrate from sewage/manure. The sewage/manure nitrate can either come from organic fertilization of fields or from septic tanks of private households. We tried to verify the information from the EM and IMM-1 model by means of a second IMM run (IMM-2, end members in Table 2). Since ureaand ammonia- fertilizers also contribute to the nitrate pool in the soils we decided to use the isotope values from soils fertilized with mineral fertilizers (Amberger and Schmidt, 1987) and not the isotope values from $\mathrm{NO}_{3}^{-}$manufactured by the Haber-Bosch process. Since the differentiation between nitrates from mineral fertilizers and sewage/manure is only meaningful for the rivers with a high share of $\mathrm{N}$ from agricultural runoff (and sewage/manure input) we selected the rivers Vistula, Oder, Peene and Paimionjoki for this new calculation. Atmospheric deposition was also included in the IMM-2, but pristine sources of nitrate were neglected.

A principal component analysis (PCA) based on a correlation matrix including all monthly mean variables was carried out with Statistica ${ }^{\circledR}$ (vers. 6). The number of available data is given in Table 1. This excluded the Swedish rivers, for which we had no component-specific isotope data. The included rivers were characterised according to their biogeochemical similarity. An ANOVA with the variables from Table 1 was carried out on the web page: http://www.physics. csbsju.edu/stats/anova.html to group rivers additionally according to single variables. 
Table 2. Characteristic end member isotope values used in calculations with the isotope mixing models. Values for nitrate from atmospheric deposition in the Kemijoki catchments given in brackets.

\begin{tabular}{|c|c|c|c|}
\hline & \multicolumn{3}{|c|}{ Isotope mixing model -1} \\
\hline & $\begin{array}{l}\mathrm{NO}_{3}^{-} \text {from agricultural } \\
\text { land }\end{array}$ & $\mathrm{NO}_{3}^{-}$from pristine soils & $\begin{array}{l}\mathrm{NO}_{3}^{-} \text {from atmospheric depo- } \\
\text { sition }\end{array}$ \\
\hline$\delta^{15} \mathrm{~N}(\% \circ)$ & $11.4^{(1)}$ & $0.6^{(1)}$ & $0.1^{(1)}\left(-0.2^{(2)}\right)$ \\
\hline \multirow[t]{3}{*}{$\delta^{18} \mathrm{O}(\% \circ)$} & $5.3^{(1)}$ & $1.4^{(1)}$ & $51.7^{(1)}\left(53.1^{(2)}\right)$ \\
\hline & \multicolumn{3}{|c|}{ Isotope mixing model -2 } \\
\hline & $\begin{array}{l}\mathrm{NO}_{3}^{-} \text {from a field after } \\
\text { mineral fertilization }\end{array}$ & $\mathrm{NO}_{3}^{-}$from sewage/ manure & $\begin{array}{l}\mathrm{NO}_{3}^{-} \text {from atmospheric depo- } \\
\text { sition }\end{array}$ \\
\hline$\delta^{15} \mathrm{~N}(\% \circ)$ & $5.0^{(3)}$ & $10.0^{(4)}$ & $0.1^{(1)}\left(-0.2^{(2)}\right)$ \\
\hline$\delta^{18} \mathrm{O}(\% \circ)$ & $6.3^{(3)}$ & $3.5^{(4)}$ & $51.7^{(1)}\left(53.1^{(2)}\right)$ \\
\hline
\end{tabular}

(1) Deutsch et al. (2006)

(2) Burns and Kendall (2002)

(3) Amberger and Schmidt (1987)

(4) Aravena et al. (1993)

Table 3. Summary characteristics of the twelve rivers and their catchments, n.a. = not available, Lule-, Kalix-, Torne-, Dal- and Ångermanälven are Swedish rivers, Kemi-, Kokemäen- and Paimionjoki are Finnish, Neva Russian, Vistula is Polish, Oder is Polish/German and Peene is German. The loads are calculated from the monthly discharge multiplied with the monthly mean concentration.

\begin{tabular}{|c|c|c|c|c|c|c|c|c|c|c|c|}
\hline \multirow[b]{2}{*}{ Rivers } & \multirow[b]{2}{*}{$\begin{array}{l}\text { Catchment } \\
\text { area }\left(\mathrm{km}^{2}\right)\end{array}$} & \multirow[b]{2}{*}{$\begin{array}{l}\text { Pop. } \\
\text { Density } \\
\left(\mathrm{km}^{-2}\right)\end{array}$} & \multirow[b]{2}{*}{$\begin{array}{l}\text { forests } \\
(\%)\end{array}$} & \multirow[b]{2}{*}{$\begin{array}{l}\text { agricult. and } \\
\text { artificial }(\%)\end{array}$} & \multirow[b]{2}{*}{$\begin{array}{l}\text { Runoff } \\
\left(* 10^{6} \mathrm{~m}^{3}\right. \\
\left.\mathrm{yr}^{-1}\right)\end{array}$} & \multirow[b]{2}{*}{$\begin{array}{l}\mathrm{DIN} \\
\left(\mu \mathrm{moll}^{-1}\right)\end{array}$} & \multicolumn{2}{|c|}{ load weighted data } & \multirow[b]{2}{*}{$\begin{array}{l}\delta^{18} \mathrm{O}-\mathrm{NO}_{3}^{-} \\
(\% \circ)\end{array}$} & \multirow[b]{2}{*}{$\begin{array}{l}\text { DIN/DIP } \\
\text { (weight } \\
\text { ratio) }\end{array}$} & \multirow[b]{2}{*}{$\begin{array}{l}\text { Atm.dep. } \\
\left(\mathrm{kg} \mathrm{N} \mathrm{km}^{-2}\right. \\
\left.\mathrm{yr}^{-1}\right)\end{array}$} \\
\hline & & & & & & & $\begin{array}{l}\text { DIP } \\
\left(\mu \mathrm{mol1}^{-1}\right)\end{array}$ & $\begin{array}{l}\delta^{15} \mathrm{~N}-\mathrm{NO}_{3}^{-} \\
(\% \circ)\end{array}$ & & & \\
\hline Lule Älv & 24934 & 1 & 62.43 & 1.02 & 16745 & 3.20 & 0.08 & $2.5^{*}$ & n.a. & 18.44 & 164.6 \\
\hline Kalix Älv & 17674 & 2 & 72.14 & 1.36 & 9951 & 5.90 & 0.12 & $2.6^{*}$ & n.a. & 22.03 & 187.8 \\
\hline Torne Älv & 39613 & 2 & 73.21 & 1.32 & 13481 & 3.66 & 0.14 & $2.8^{*}$ & n.a. & 12.15 & 155.5 \\
\hline Dalälven & 28873 & 9 & 86.12 & 5.44 & 11911 & 10.48 & 0.10 & $3.1 *$ & n.a. & 48.56 & 526.8 \\
\hline Ångermanälven & 31421 & 2 & 85.40 & 2.78 & 16910 & 4.34 & 0.07 & $2.3^{*}$ & n.a. & 29.07 & 255.3 \\
\hline Vistula & 192899 & 121 & 33.16 & 65.54 & 33637 & 174.29 & 3.79 & 7.3 & 12.3 & 20.76 & 1117.4 \\
\hline Oder & 117589 & 138 & 32.61 & 66.06 & 16872 & 216.45 & 4.40 & 8.3 & 13.4 & 22.22 & 1694.5 \\
\hline Peene & 4944 & 61 & 17.00 & 81.00 & 582 & n.a. & n.a. & 7.1 & 13.0 & 58.76 & n.a. \\
\hline Paimionjoki & 1145 & 19 & 56.49 & 42.14 & 278 & 141.91 & 4.42 & 6.7 & 13.3 & 14.49 & 692.4 \\
\hline Kokenmäenjoki & 26667 & 30 & 78.66 & 10.85 & 8078 & 50.05 & 0.85 & 5.5 & 15.5 & 26.74 & 590.8 \\
\hline Kemijoki & 50918 & 2 & 83.63 & 3.30 & 18542 & 5.68 & 0.23 & -0.1 & 19.5 & 11.01 & 207.2 \\
\hline Neva & 285835 & 23 & 67.70 & 15.12 & 79665 & 23.56 & 0.29 & 2.4 & 20.9 & 36.25 & 442.8 \\
\hline
\end{tabular}

$* \delta^{15} \mathrm{~N}$ of total nitrogen, since concentration of nitrate+nitrite was too low.

\section{Results}

\subsection{Sites description - differences between catchments}

The catchment of the Baltic Sea stretches from $68^{\circ} \mathrm{N}$ to $49.5^{\circ} \mathrm{N}$ and thus covers a wide span of climatic conditions from subarctic to temperate (Fig. 1). The Baltic Sea sub-catchments studied here vary in area from almost $300000 \mathrm{~km}^{2}$ for the Neva to 1100 for the Paimionjoki (Table 3). Accordingly, we find a wide range of natural variability in vegetation cover, land use and population density (Table 3). The nitrogen deposition in the precipitation of the catchments correlates well with the population density $\left(\mathrm{n}=11, \mathrm{r}^{2}=0.897, \mathrm{p}<0.001\right)$, varying from $200 \mathrm{~kg} \mathrm{~N} \mathrm{~km}^{-2}$ $\mathrm{yr}^{-1}$ in the Kemijoki catchments with just 2 individuals $\mathrm{km}^{-2}$ to almost $1700 \mathrm{~kg} \mathrm{~N} \mathrm{~km}^{-2} \mathrm{yr}^{-1}$ in the Oder River catchments with mean population of 138 individuals $\mathrm{km}^{-2}$ (Table 3 ). Today the southern catchments have much less forests than the northern ones, although deforestation over the past 40-50 years almost ceased. The Peene catchment has only $17 \%$ forests left, while the Swedish watersheds, the Finnish Kemjoki river catchment and part of the Neva catchments have largely kept their original vegetation and still have up to $86 \%$ forests (Table 3). However, Kemijoki is highly fragmented by damming (http://earthtrends.wri.org/) like the Swedish rivers Lule Älv and Ångermanälven (Humborg et al., 2002). Flow-weighted winter $\mathrm{NO}_{3}^{-}$concentrations vary 


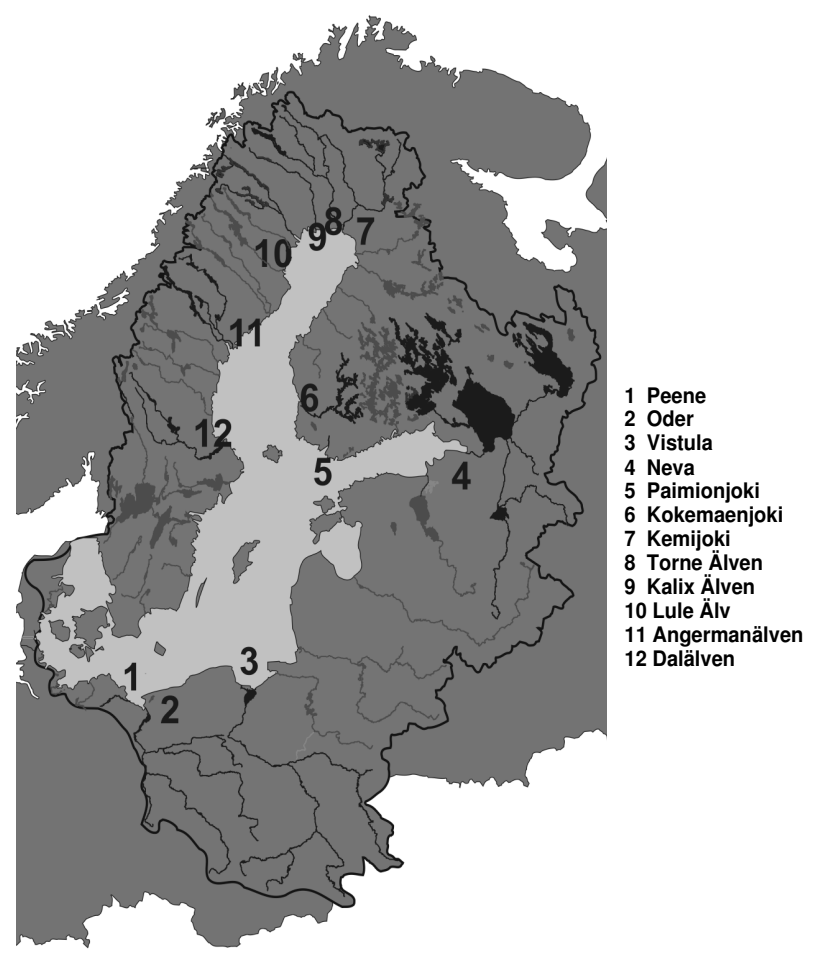

Fig. 1. The Baltic Sea and its catchments, with investigated rivers in black and numbered 1 to 12 .

from 10 and $27 \mu \mathrm{mol}^{-1}$ in Kemijoki and Neva, respectively, to $270 \mu \mathrm{moll}^{-1}$ in the Vistula (Table 3, Figs. 2-4). Artificial and agricultural used areas range from $1 \%$ for the Lule Älv to $81 \%$ for the Peene River (Table 3).

\subsection{Annual patterns in nutrient and stable isotope data}

Averaged monthly data from three rivers, the Vistula (Fig. 2), the Oder (Fig. 3), and the Kemijoki (Fig. 4) show clear seasonal patterns. Water flows are usually highest in February to April; the northernmost river, Kemijoki, has its peak flow in May. Nitrate concentrations co-vary with the flow for the rivers with high nutrient concentrations (Figs. 2-3), and for the Kemijoki, nitrate concentrations peak before the flow (Fig. 4). This means that highest nitrate loads are delivered to the coastal zones in late winter and early spring. Since nitrate is the most abundant inorganic nitrogen form, the DIN/DIP ratios in all the rivers are almost always above 16 (the Redfield ratio) and have highest deviations from the Redfield ratio in March through May (up to 189 was reached in the Vistula River in January/February 2002). The $\delta^{15} \mathrm{~N}^{-\mathrm{NO}_{3}^{-}}$values are usually higher in summer than in winter. PON concentrations have clear peaks in spring and summer (similarly to POC, not shown), while their corresponding isotope values have no obvious relationship to the PON. The $\delta^{15} \mathrm{~N}$ of the PON is not correlated with the PON loads.

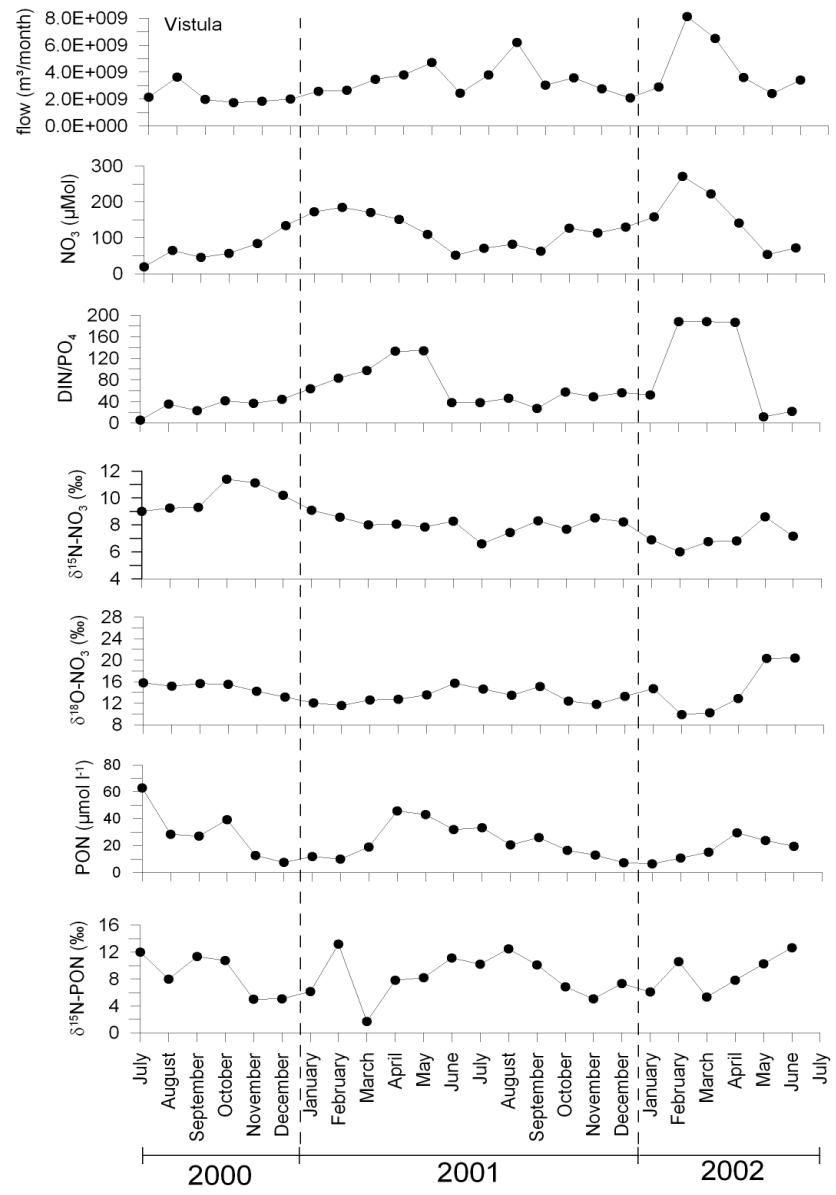

Fig. 2. The two annual cycles for the Vistula River, July 2000 to June 2002. Water flow as monthly means, nutrient data as monthly means, based on biweekly sampling, with concentrations flow-weighted and isotope values load-weighted.

A comparison of all rivers reveals a similar variation in $\delta^{15} \mathrm{~N}-\mathrm{NO}_{3}^{-}$, with decreasing values from winter towards spring and an increasing trend towards summer (except for the Vistula, Fig. 5a). Here the development in the Kemijoki lags the more southern rivers. An amplitude as high as $8 \%$ was found in the southern rivers Vistula and Oder versus only $3 \%$ in the Kemijoki. We measured up to $13.2 \%$ in the Oder River while the Kemijoki had a $\delta^{15} \mathrm{~N}$ value of $-1.6 \%$ o in winter 2000/2001 (Fig. 5a). In the Swedish river Lule Älv we measured an even lower value of $<-3 \%$. All other rivers were in between these extremes. Differences between years are also obvious with a clearer seasonal variation in the sampling period 2000/2001 than in 2001/2002. A peak in $\delta^{15} \mathrm{~N}$ $\mathrm{NO}_{3}^{-}$in summer was detectable for the Oder, Peene, and Paimionjoki, where we had the highest DIN loads among all rivers investigated (Fig. 5a) and $>40 \%$ of farmland. The Vistula, while belonging to the same group of farmland dominated catchments (66\%), had a less clear isotopic pattern than the Oder, Peene, and Paimionjoki and no $\delta^{15} \mathrm{~N}^{-\mathrm{NO}_{3}^{-}}$peak 


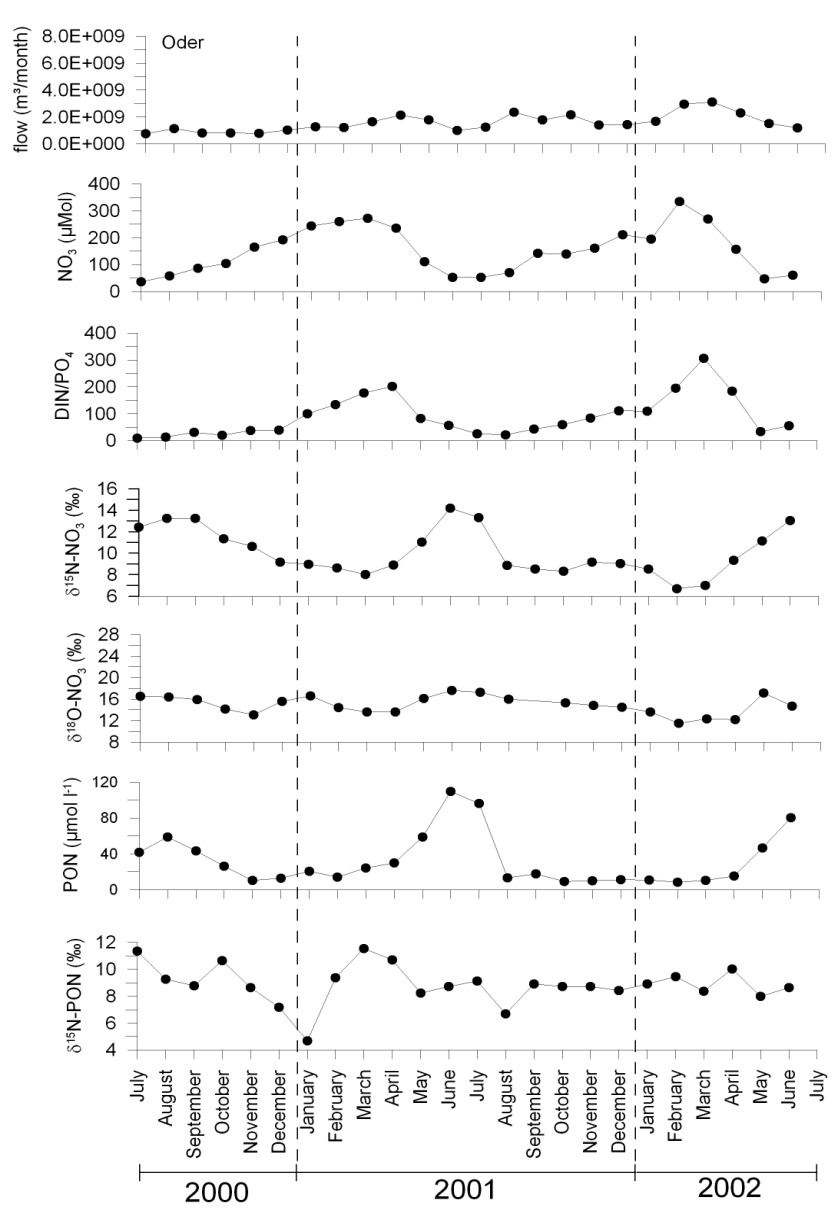

Fig. 3. The two annual cycles for the Oder River from July 2000 to June 2002. Water flow as monthly means, nutrient data as monthly means, based on biweekly sampling, with concentrations flow-weighted and isotope values load-weighted.

in summer. The $\delta^{15} \mathrm{~N}-\mathrm{NO}_{3}^{-}$values from the Kokemaenjoki were highest in winter with only a slight peak in late summer and are thus similar to those in the rivers described above, although the catchments are dominated by $79 \%$ forests (Table 3). Kemijoki and Neva River have considerably lower load weighted $\delta^{15} \mathrm{~N}$ values of -0.1 and $2.4 \%$ o, respectively. The Kemijoki has small peaks before the actual spring flow occurs (Fig. 4). Neva $\delta^{15} \mathrm{~N}-\mathrm{NO}_{3}^{-}$data show no seasonal pattern (Fig. 5a) which may be due to a "buffering effect" of the huge Lake Ladoga, located some $70 \mathrm{~km}$ upstream from the city of St. Petersburg (Kuuppo et al., 2006). Lake Ladoga prolongs the residence of the water and receives precipitation modifying the original isotope patterns in the catchment.

The $\delta^{18} \mathrm{O}-\mathrm{NO}_{3}^{-}$river data vary less with season than the $\delta^{15} \mathrm{~N}$ (Fig. 5b), but the Vistula, Oder and Peene show elevated values in summer. The $\delta^{18} \mathrm{O}$ values are lowest in the southern Polish and German rivers and in the Paimionjoki, and higher in the Nordic rivers (Fig. 5b, Table 3). Values over 20\%o are only found in the Nordic rivers at relatively low nitrate concentrations $\left(<25 \mu \mathrm{mol}^{-1}\right)$.

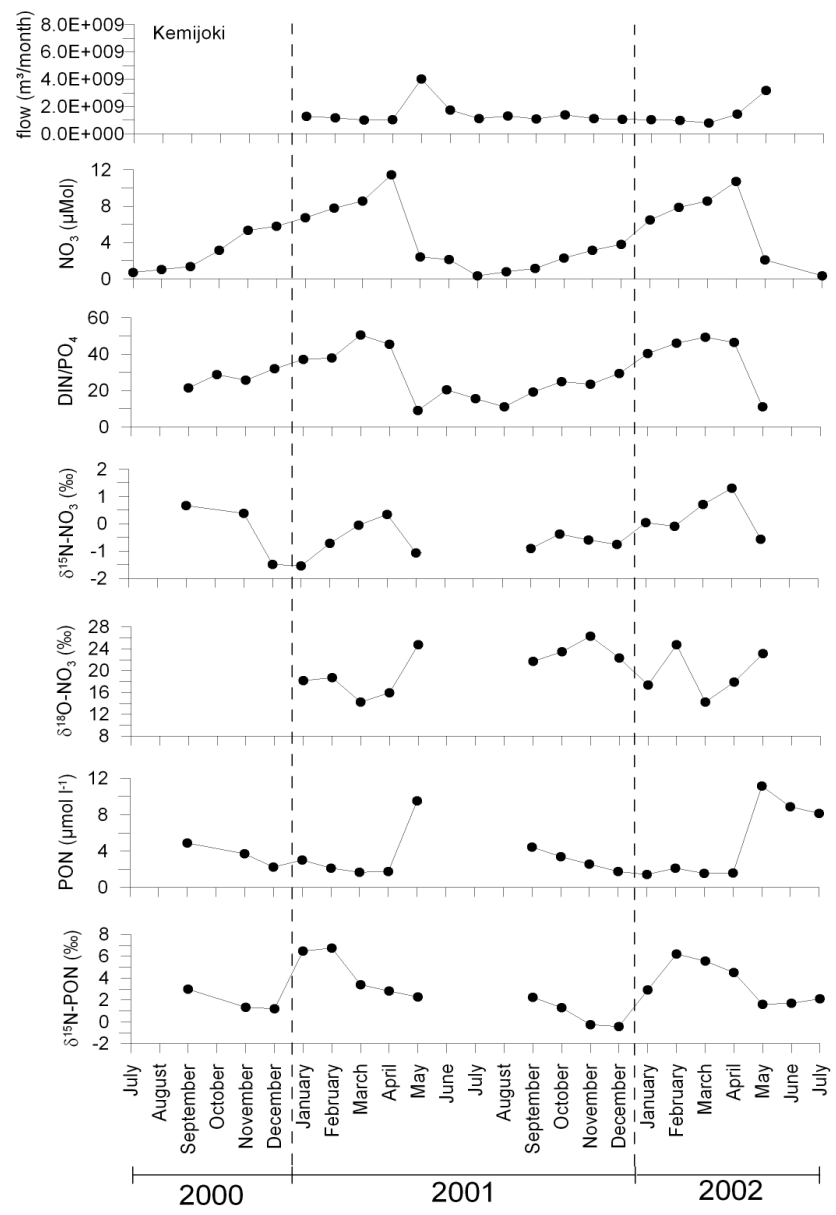

Fig. 4. The two annual cycles for the Kemijoki from July 2000 to June 2002. Water flow as monthly means, nutrient data as monthly means, based on monthly sampling, with concentrations flow-weighted and isotope values load-weighted.

\subsection{Statistical analysis}

A principal component analysis (PCA) explained $94.8 \%$ of the variance in the first three eigenvectors and thus found almost identity between pairs of rivers: Vistula and Oder, Neva and Kemijoki and similarity between Kokemaenjoki and Paimionjoki. The Peene River was slightly separate from all others (Fig. 6). However, the ANOVA test showed that the similarity between variables was rather complex, e.g. $\mathrm{NO}_{3}^{-}$ concentrations of the Vistula, Oder and Peene were indistinguishable, likewise the ones from Paimionjoki, Kokemaenjoki, Kemijoki, and Neva. The $\mathrm{PO}_{4}^{3-}$ concentrations from the Vistula, Oder, Peene, and Kokemaenjoki were indistinguishable and also for the other three rivers, Kemijoki, Neva, and Paimiojoki. The identification of two main groups of rivers and separation of the southern rivers from the Nordic ones was possible based on the isotope data of nitrate. 

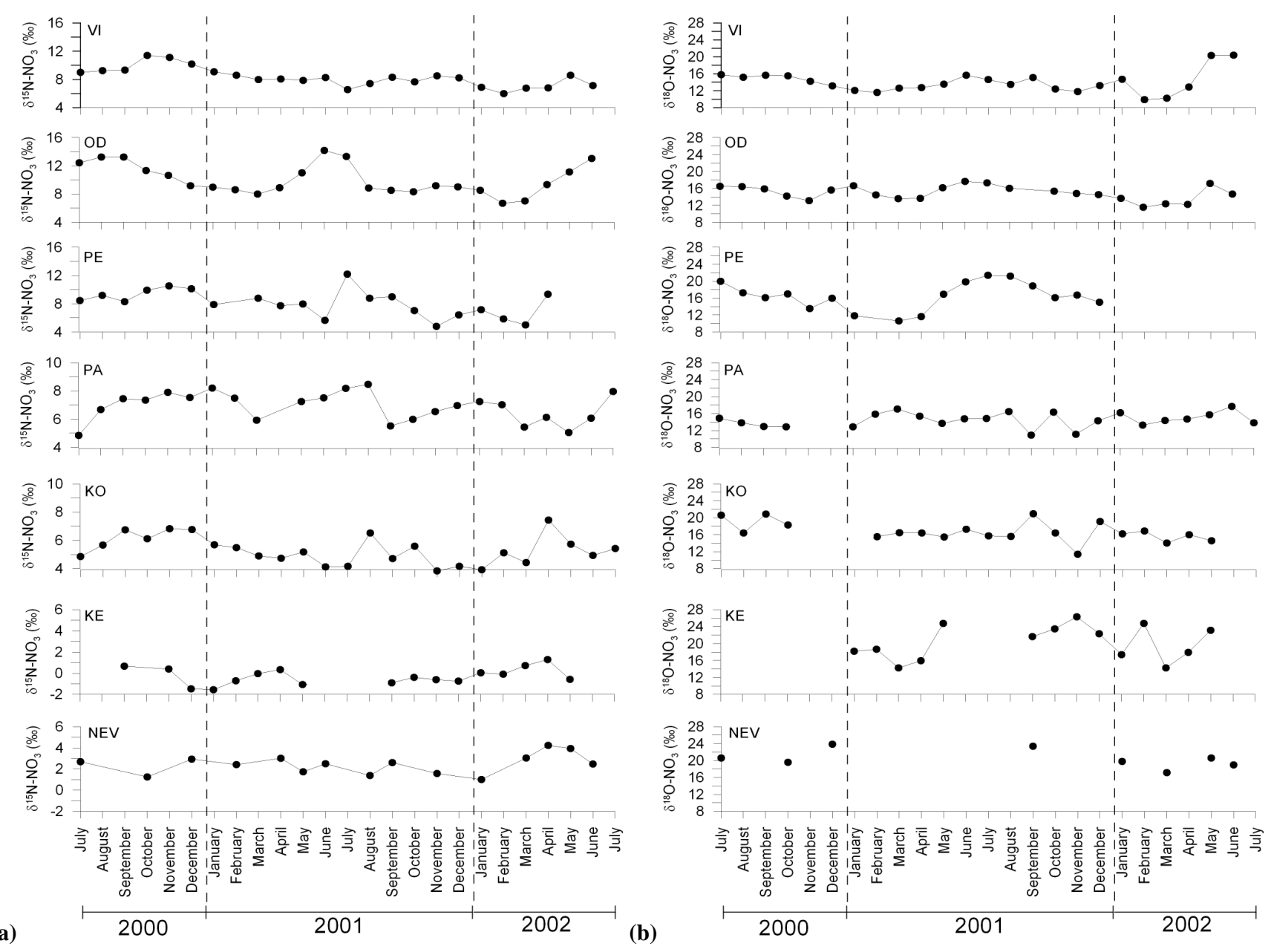

Fig. 5. (a) load weighted monthly $\delta^{15} \mathrm{~N}_{-} \mathrm{NO}_{3}^{-}$values from all except the Swedish rivers (b) load weighted monthly $\delta^{18} \mathrm{O}-\mathrm{NO}_{3}^{-}$values from all rivers except the Swedish rivers.

3.4 Land use, isotopic composition of nitrate and source attribution

The anthropogenic nitrate sources that are considered in the following text are either from farmland fertilized with manure or mineral fertilizer summarized as mixed fertilizer, or from sewage from septic tanks of private households and sewage treatment plants (STP). The organic N-sources are usually summarized as manure/sewage. Additionally, nitrate from atmospheric deposition and from pristine soils is evaluated. Pristine, is defined here as those soils/forests that are not intensively used but may be affected by $\mathrm{N}$-deposition.

There was a positive correlation between the load weighted $\delta^{15} \mathrm{~N}_{-} \mathrm{NO}_{3}^{-}$values and the share of farmland/agricultural land in the catchments, as calculated from GLC data (Table 4, Fig. 7), and a less significant negative relationship with the $\delta^{18} \mathrm{O}-\mathrm{NO}_{3}^{-}$values (Table 4, Fig. 7). Forest coverage also correlated with the annual mean $\delta^{18} \mathrm{O}$ data, but positively. Other land use categories like wetland, bare land, ice or snow were not considered in detail since they are only relevant for the Nordic rivers. The IMM-1 results independently confirm that low $\delta^{15} \mathrm{~N}$ values and high $\delta^{18} \mathrm{O}$ values result from pristine nitrate sources, while the southern rivers receive up to $80 \%$ of their nitrate from soils with mixed fertilization and sewage (Fig. 8a). We also used a source emission model (EM) which allowed distinction between nitrate from sewage/manure and mineral fertilizer and atmospheric deposition (Table 4), but did not include pristine soil runoff. Thus, atmospheric deposition was the only source category included in both models. However, if we summed nitrate from sewage/manure plus mineral fertilizer in the $\mathrm{EM}$ we got an approximately $20 \%$ larger share of $\mathrm{NO}_{3}^{-}$from agricultural runoff than in IMM-1 (Table 4).

We then tested the EM results with an IMM calculation (IMM-2) using the end members mineral fertilizer, sewage/manure and atmospheric deposition (Fig. 8b). The calculation was done for the catchments with $>50 \% \mathrm{~N}$ from agricultural runoff in IMM-1. The IMM-2 results confirmed 
Table 4. Proportion of nitrate from different sources, calculated using two isotope mixing models (IMM-1 and IMM-2), an emission model (EM), and land use data from the Global Land Cover data base (GLC). For further explanation see text. n.a. = not available.

\begin{tabular}{|c|c|c|c|c|c|c|c|c|c|c|c|c|}
\hline & \multicolumn{3}{|c|}{ IMM-1 results } & \multicolumn{3}{|c|}{ IMM-2 results } & \multicolumn{3}{|c|}{ Emission model (EM) results } & \multicolumn{3}{|c|}{ Land use in catchment, from GLC } \\
\hline & $\begin{array}{l}\% \mathrm{~N} \\
\text { from agri- } \\
\text { cultural } \\
\text { runoff }\end{array}$ & $\begin{array}{l}\% \mathrm{~N} \text { from } \\
\text { pristine } \\
\text { soils }\end{array}$ & $\begin{array}{l}\% \mathrm{~N} \text { from } \\
\text { Atm. Dep. }\end{array}$ & $\begin{array}{l}\% \mathrm{~N} \text { from } \\
\text { sewage } \\
\text { and ma- } \\
\text { nure }\end{array}$ & $\begin{array}{l}\% \mathrm{~N} \text { from } \\
\text { mineral } \\
\text { fertilizer }\end{array}$ & $\begin{array}{l}\% \mathrm{~N} \text { from } \\
\text { Atm. Dep. }\end{array}$ & $\begin{array}{l}\% \mathrm{~N} \text { from } \\
\text { sewage } \\
\text { and ma- } \\
\text { nure }\end{array}$ & $\begin{array}{l}\% \mathrm{~N} \text { from } \\
\text { mineral } \\
\text { fertilizer } \\
(\%)\end{array}$ & $\begin{array}{l}\% \mathrm{~N} \text { from } \\
\text { Atm. Dep. }\end{array}$ & $\begin{array}{l}\text { Agricult. } \\
\text { and artif. } \\
(\%)\end{array}$ & $\begin{array}{l}\text { Forests } \\
(\%)\end{array}$ & $\begin{array}{l}\text { wetland, } \\
\text { bare, water } \\
(\%)\end{array}$ \\
\hline Vistula & 0.63 & 0.20 & 0.17 & 0.63 & 0.20 & 0.17 & 0.32 & 0.49 & 0.19 & 0.66 & 0.33 & 0.01 \\
\hline Oder & 0.73 & 0.09 & 0.18 & 0.87 & 0.00 & 0.21 & 0.33 & 0.45 & 0.22 & 0.66 & 0.33 & 0.01 \\
\hline Peene & 0.61 & 0.20 & 0.19 & 0.60 & 0.21 & 0.19 & n.a. & n.a. & n.a. & 0.81 & 0.17 & 0.02 \\
\hline Paimionjoki & 0.58 & 0.23 & 0.19 & 0.53 & 0.29 & 0.19 & 0.11 & 0.29 & 0.60 & 0.42 & 0.56 & 0.01 \\
\hline Kokenmäenjoki & 0.47 & 0.29 & 0.24 & - & - & - & 0.19 & 0.45 & 0.36 & 0.11 & 0.79 & 0.10 \\
\hline Kemijoki & 0.00 & 0.67 & 0.33 & - & - & - & 0.02 & 0.00 & 0.98 & 0.03 & 0.84 & 0.13 \\
\hline Neva & 0.18 & 0.45 & 0.37 & - & - & - & 0.19 & 0.21 & 0.60 & 0.15 & 0.68 & 0.17 \\
\hline
\end{tabular}

the IMM-1 calculation in that all rivers with high nitrate concentrations also had high contributions from mineral fertilization and only 0 to $21 \%$ from sewage/manure. The percentages for sewage/manure from the IMM-2 are well correlated with the percentages of nitrate from agricultural land from IMM-1 but less with the GLC estimates (Table 3, Fig. 9a). For nitrate from atmospheric deposition, IMM-1 and -2 give very similar contributions (Fig. 9b), since $\delta^{15} \mathrm{~N}$ values of atmospheric deposition do not overlap with the chosen values for soil nitrate after mineral fertilization. The $\mathrm{N}$ from pristine soils, estimated with the IMM-1, gives percentages that were between the ones from GLC data for forests and wetland/bare, respectively (Fig. 9c).

\section{Discussion}

4.1 Seasonal variation in the isotopic composition of riverine nitrate

Seasonal changes in nutrient and particulate matter concentrations in rivers are caused by variability in soil runoff and discharge, and in autochthonous production and degradation of organic matter (Battaglin et al., 2001). A number of studies have used isotopic data to attempt to unravel these processes, and to distinguish them from source signals, which can also vary (Chang et al., 2002; Harrington et al., 1998; Mayer et al., 2002; McClelland et al., 1997). It is important to evaluate how the variability of the source signals affects the reliability of the calculated source attributions. We are aware that it might be difficult to fully disentangle the contribution of various anthropogenic sources such as nitrate from sewage vs. nitrate from diffusive sources due to a lack of published $\delta^{15} \mathrm{~N}$ and $\delta^{18} \mathrm{O}-\mathrm{NO}_{3}^{-}$data as end members. Therefore, we discuss our results with caution when it comes to the relative share of point sources versus diffusive sources in the cultivated watersheds. However, this study aims additionally to show large scale isotopic patterns relevant to the Baltic Sea catchment and the adjacent major basins of the Baltic Sea. Nitrate concentration is significantly nega- tively correlated with $\mathrm{N}$-isotope values in the Oder $(r=0.84$, $p>0.001, n=24)$ and Vistula waters $(r=0.46, p>0.02, n=24)$ suggesting that biological fractionation during in-stream nitrate consumption is important. The fractionation effect is know from laboratory cultures and the marine environment (Montoya and McCarthy, 1995). The $\delta^{15} \mathrm{~N}-\mathrm{NO}_{3}^{-}$data from the Oder (Fig. 3) show this fractionation very clearly. Similar results are reported for sites in the agricultural Mississippi River Basin (Chang et al., 2002). Isotopically heavy nitrate may additionally be generated during denitrification when river water infiltrates through soils (Grischek et al., 1997) or riparian river zones (Sebilo et al., 2003). The sharp increase in the N:P ratios in summer also suggest nitrate uptake until phosphate limitation occurs. Denitrification and nitrification in soils are effective around the year, especially nitrification after fertilization with ammonia and urea compounds. The latter process would lower the $\delta^{15} \mathrm{~N}$ in the $\mathrm{NO}_{3}^{-}$generated, but usually uptake and denitrification raise the isotope values immediately so that isotope values rise with increasing depth in the soil (Nadelhoffer and Fry, 1994). Therefore, high $\delta^{15} \mathrm{~N}-\mathrm{NO}_{3}^{-}$values in the rivers may result from nitrification/denitrification transformation. Chang et al. (2002) identified different $\mathrm{N}$-sources by means of the isotopes values in river nitrate. They assume that isotopically heavy soil$\mathrm{N}$ in winter is from manure, and that mineral fertilizers influence the soil-N signatures in spring. Although the Oder and Vistula both drain catchments with up to $66 \%$ of agriculture land, it seems unlikely that much fertilizer $\mathrm{N}$ enters the rivers directly. Usually the nitrogen is processed in the soils before it enters a river. Livestock and septic tanks effluents may add nitrogen rather directly - as do sewage treatment plants. These sources are known to have high $\delta^{15} \mathrm{~N}$ $\mathrm{NO}_{3}^{-}$values of up to $14 \%$ (Aravena et al., 1993) or even $20 \%$ (Heaton, 1986). Isotopically heavy sources are responsible for the overall high $\delta^{15} \mathrm{~N}$ values in Oder, Vistula, Peene and Paimionjoki and seem to further increase when biological production e.g. phytoplankton growth starts.

The highest PON concentrations were recorded in summer, supporting an origin from autochthonous production in 


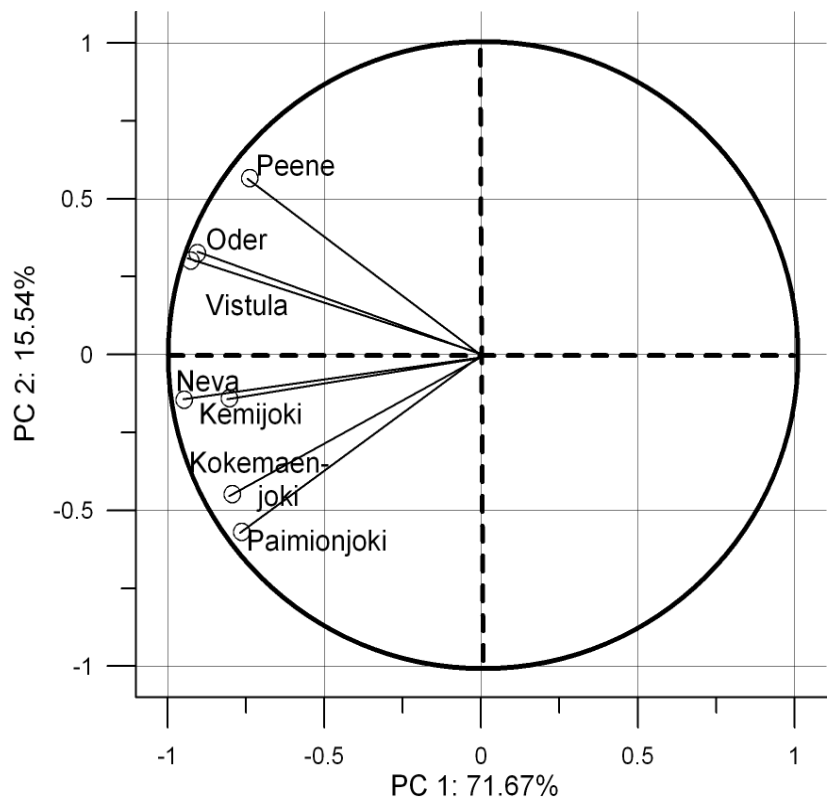

Fig. 6. Factorial analysis of all river data - except for the Swedish rivers - performed with Statistica ${ }^{\circledR}$ ver. 6 .

the rivers, but there was no clear relationship to the isotope signal. This is to be expected when a variety of $\mathrm{N}$-sources reach the river, where assimilation and dissimilation processes occur simultaneously (Battaglin et al., 2001; Kendall et al., 2001).

Forests in northern Scandinavia are little affected by anthropogenic fertilization (Humborg et al., 2004) and presumably leach nitrate from soils that have similar $\delta^{15} \mathrm{~N}^{-\mathrm{NO}_{3}^{-}}$values as in the case of rivers draining mainly forested catchments in North America, where values $<5 \%$ (Mayer et al., 2002) and 2\%o (Harrington et al., 1998) are reported. The Kemijoki, with a catchment of over $80 \%$ forest, has the lowest $\delta^{15} \mathrm{~N}$ values of all sampled rivers (load weighted mean: $-0.1 \%$ ). Furthermore, it has a positive relationship $(r=0.42$, $p>0.1$ ) between monthly mean nitrate concentration and $\delta^{15} \mathrm{~N}$. Since the nitrate concentration and the $\delta^{15} \mathrm{~N}$ increase almost simultaneously until April 2002 and then drop (Fig. 4) there must have been a source of nitrate with low $\delta^{15} \mathrm{~N}$ values and low nitrate concentrations in April 2002. This could have been nitrate from pristine soils or from atmospheric deposition. The increasing $\delta^{18} \mathrm{O}$ values also suggest nitrate from snowmelt since $\delta^{18} \mathrm{O}-\mathrm{NO}_{3}^{-}$in snow from Greenland is reported with $65-80 \%$ (Hastings et al., 2004) and from the Rocky Mountains with 46-55\% in the precipitation (Burns and Kendall, 2002). Even a low contribution of $\mathrm{NO}_{3}^{-}$with these high values could easily raise our winter $\delta^{18} \mathrm{O}$ signal of $14-15 \%$ o to $>26 \%$ o in spring and simultaneously dilute the $\mathrm{NO}_{3}^{-}$concentration in the rivers. This is supported by our finding of the spring flow peak which coincides with increased $\delta^{18} \mathrm{O}-\mathrm{NO}_{3}^{-}$values (Fig. 4).

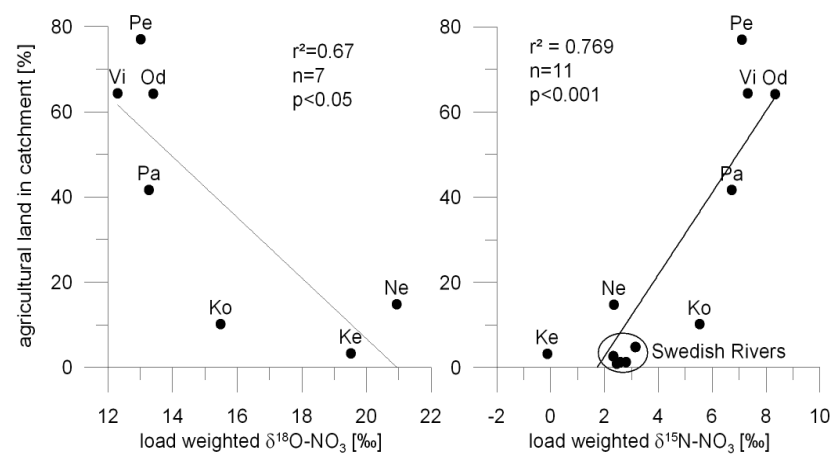

Fig. 7. Agricultural land in the catchments from the GLC data base over weighted monthly means of $\delta^{15} \mathrm{~N} \mathrm{NO}_{3}^{-}$and $\delta^{18} \mathrm{O}-\mathrm{NO}_{3}^{-}$ of the non-Swedish rivers. $\delta^{15} \mathrm{~N}$ of Swedish rivers refer to total N. Abbreviations are: Ke=Kemijoki, Ko=Kokemaenjoki, Ne=Neva, $\mathrm{Od}=$ Oder River, $\mathrm{Pa}=$ Paimionjoki, $\mathrm{Pe}=$ Peene, $\mathrm{Vi}=$ Vistula River.

Although we find the same negative relationship of $\mathrm{NO}_{3}^{-}$ concentration over $\delta^{18} \mathrm{O}-\mathrm{NO}_{3}^{-}$in the Vistula and Oder rivers we assume here that ${ }^{18} \mathrm{O} /{ }^{16} \mathrm{O}$ fractionation during primary production is the reason, since nitrate uptake fractionates ${ }^{18} \mathrm{O} /{ }^{16} \mathrm{O}$ in the same way as it does for ${ }^{15} \mathrm{~N} /{ }^{14} \mathrm{~N}$ (Granger et al., 2004).

Seasonal changes in monthly concentration and isotopic compositions were also observed in the rivers Kokemaenjoki, Paimionjoki, Neva, Peene and the Swedish Rivers (Fig. 5), but those are not discussed in detail. Nevertheless, significant differences exist among the rivers in annual mean isotope values. Although the river isotope signatures change with season, we show that differences in the annual mean isotopic composition of nitrate can be related to land use (Fig. 7). Annual means should be more reliable than measurements at any single time of the year.

Our highest $\delta^{15} \mathrm{~N}-\mathrm{NO}_{3}^{-}$and lowest $\delta^{18} \mathrm{O}-\mathrm{NO}_{3}^{-}$values were recorded in rivers with catchments dominated by fields and agricultural land. However, these catchments also have population densities $>50$ inhabitants $\mathrm{km}^{-2}$ and may therefore be more affected by effluents from STPs than catchments of the other rivers studied. Both $\mathrm{N}$-sources have high nitrate (and potentially high ammonium) concentrations and contribute to the in- stream DIN concentrations. They cannot clearly be differentiated by the applied stable isotope methods. Sewage/manure can thus come from agricultural practices and STP alike.

\subsection{Comparison of GLC based land use estimates with iso- tope data}

There is a highly significant relationship between GLCderived estimates of agricultural land area and $\delta^{15} \mathrm{~N}^{-\mathrm{NO}_{3}}$ (Fig. 7) which spans a range from -0.1 to $8.3 \%$. The same relationship was found for a river system in Vermont, where 

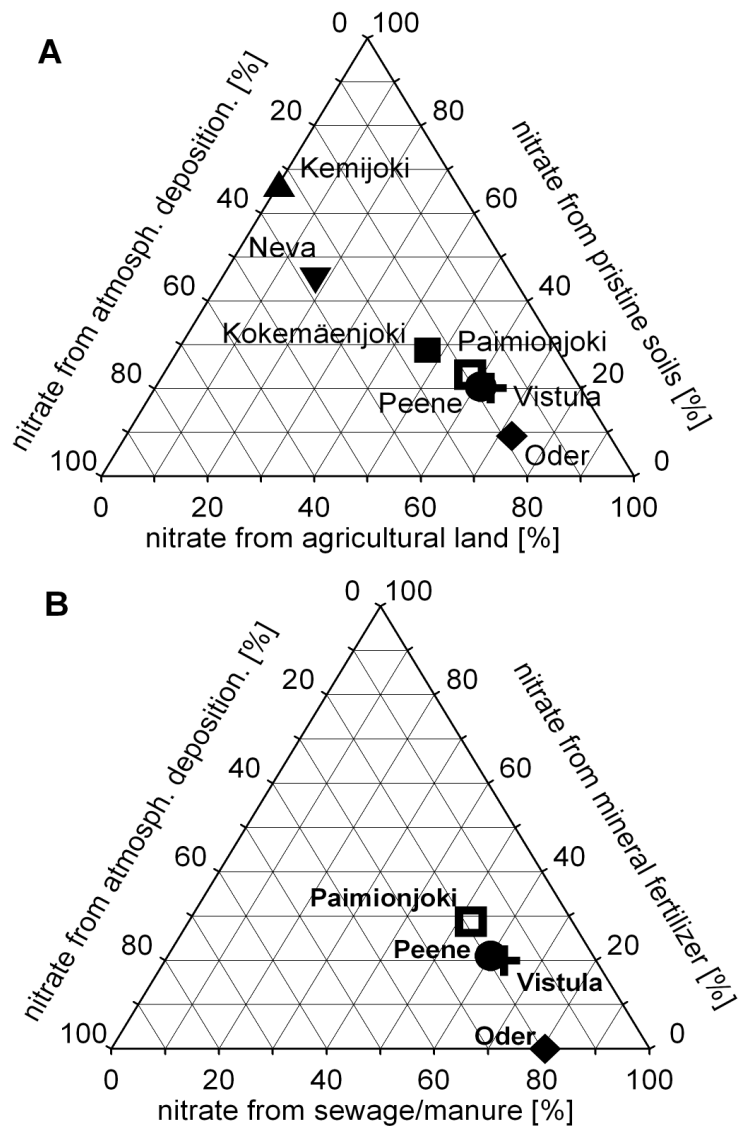

Fig. 8. Ternary mixing diagrams based on the IMM-1 (A) and IMM-2 (B) results (Phillips and Koch, 2002).

$\delta^{15} \mathrm{~N}-\mathrm{NO}_{3}^{-}$values of 2.0 to $7.3 \%$ were measured (Harrington et al., 1998).

Nitrate leaching from over-fertilized soils is known to be high in $\delta^{15} \mathrm{~N}$ for several reasons, as shown by Aravena et al. (1993) and Chang et al. (2002). Denitrification raises the $\delta^{15} \mathrm{~N}$ in anoxic zones of the soils (Ostrom et al., 1998). The nitrate isotope values increase with depth in the soil, suggesting a sequestering and fractionation of nitrogen bearing compounds with depth (Nadelhoffer and Fry, 1994). Mineral fertilizer is manufactured with a $\delta^{15} \mathrm{~N}_{-} \mathrm{NO}_{3}^{-}$of $0 \%$ (Amberger and Schmidt, 1987) but such low values are not found at depth in soil (Nadelhoffer and Fry, 1994). Ammonia volatilises under basic conditions and is fractionated, which leads to increasing isotope values in the remaining $\mathrm{NH}_{4}^{+}$ (Flipse and Bonner, 1985). Values of $\delta^{15} \mathrm{~N}>10 \%$ seem therefore to be typical for the contribution of manure/sewage from either animal husbandry or STPs (Aravena et al., 1993; Fogg et al., 1998; McClelland and Valiela, 1998). Such nitrogen retains a high isotope value (even though the $\delta^{15} \mathrm{~N}$ is lowered when the compound is first nitrified), which is further increased by subsequent processing (Kendall, 1998). Therefore, not only the amount of fertilizer, but also the ve-
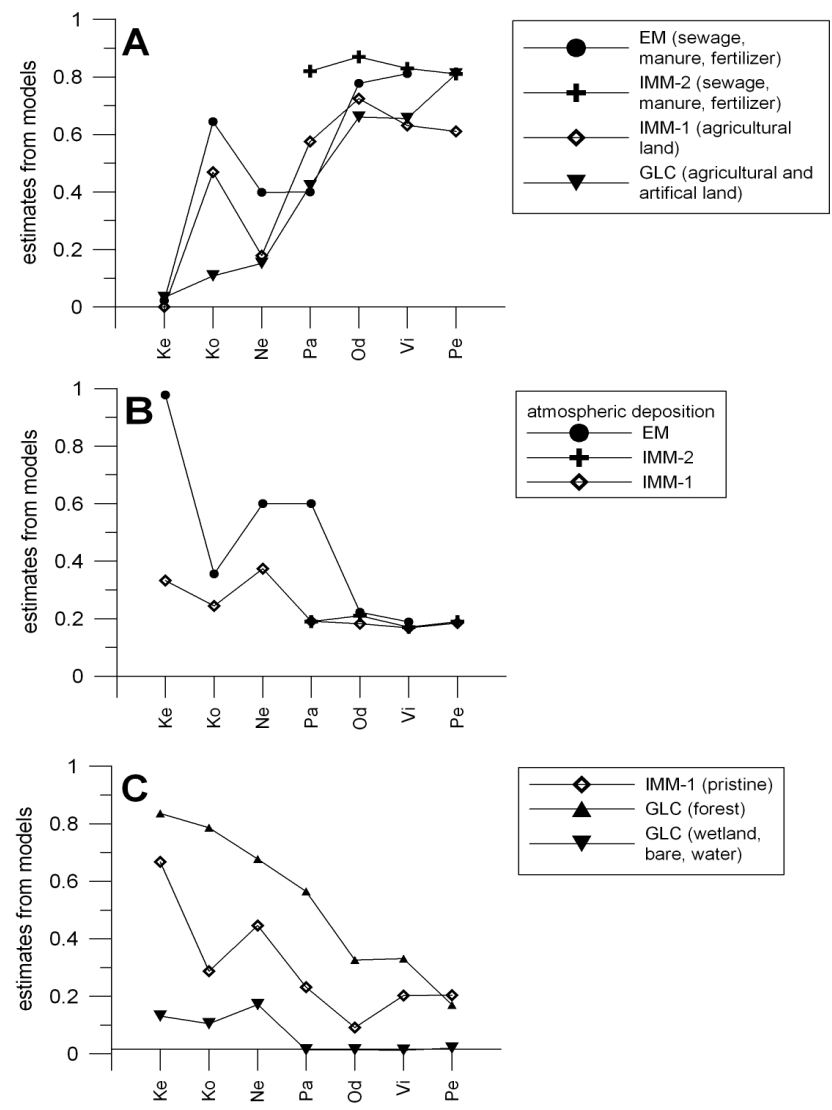

Fig. 9. Relative fraction of nitrogen from specific sources as calculated by the different models, the global land cover data base (GLC), the isotope mixing models (IMM) 1 and 2, and the emission model (EM) A) shows the fractions from mixed fertilisation given by EM and IMM-2, runoff from farmland (IMM-1), and agricultural land in catchments from GLC B) the $\mathrm{N}$ fraction from atmospheric deposition and $\mathrm{C}$ ) fraction of $\mathrm{N}$ from pristine land (IMM-1), forests (GLC), and wetland, bare, water (GLC). Please note that the IMM2 run was only performed for the heavily fertilized catchments of the rivers Paimionjoki, Peene, Oder, and Vistula.

locity of the downward water flow determines the isotope values of the soil water and the soil runoff. Our $\delta^{15} \mathrm{~N}$ data from the Oder, Vistula, Peene, and Paimionjoki are lower than sewage/manure but considering the variability of the isotope data we assume that this source and/or the soil runoff from farmland comprise the major riverine nitrate sources. The Kokemaenjoki has little agricultural land (11\%) and much forest $(79 \%)$ in its catchments which is mirrored in lower $\delta^{15} \mathrm{~N}_{-} \mathrm{NO}_{3}^{-}(\sim 5.5 \%$ o $)$ values. The forests in the Kokemaenjoki and Kemijoki catchments can be regarded as nearpristine, and they receive little or no artificial fertilisation. Accordingly, the share of forest coverage is negatively correlated with $\delta^{15} \mathrm{~N}-\mathrm{NO}_{3}^{-}$, a result also found in other studies (Harrington et al., 1998; Mayer et al., 2002).

The $\delta^{18} \mathrm{O}$ values of nitrate from our rivers fall in the range reported for the Mississippi River Basin (Chang et al., 2002). 
Our annual means of $12-13 \%$ in the Vistula, Oder, Peene and Paimionjoki seem to be typical for agricultural soils, while higher $\delta^{18} \mathrm{O}$ values from Kokemaenjoki, Kemijoki, and Neva (15-19\%o) indicate nitrate originating from nitrification in forest floors (Mayer et al., 2001) and/or a contribution from the snow melt (Burns and Kendall, 2002). The $\delta^{18} \mathrm{O}$ values in $\mathrm{NO}_{3}^{-}$generated through nitrification in the soils depends on the water source $\delta^{18} \mathrm{O}$ (Mayer et al., 2001). Our negative relationship between the load weighted $\delta^{18} \mathrm{O}-\mathrm{NO}_{3}^{-}$ and agricultural land (Fig. 7) is consistent with this conclusion. Furthermore, a plot of $\delta^{18} \mathrm{O}$ over the percentages of forests in the catchments gives a weak positive correlation $(n=7, r=0.73, p<0.1)$. Bare land and open water only occurs in significant shares in the northern catchments and the nitrate in the precipitation could have raised our $\delta^{18} \mathrm{O}-\mathrm{NO}_{3}^{-}$. Thus, $\delta^{18} \mathrm{O}$ values are heavily influenced by land use practices in the southern catchments and by nitrification in forest soils plus contributions from snow melt and rain in the northern catchments.

We conclude that $\delta^{15} \mathrm{~N}-\mathrm{NO}_{3}^{-}$values of $6-8 \%$ indicate $>60 \%$ artificial/agricultural land in the catchment, and that $>65 \%$ forests results in $\delta^{15} \mathrm{~N}_{-} \mathrm{NO}_{3}^{-}$-values $<6 \%$. Soil processing after fertilization gives $\delta^{18} \mathrm{O}-\mathrm{NO}_{3}^{-}$values of about $13 \%$, while values above $15 \%$ o suggest a predominance of nitrate from nitrification in pristine forest soils and melting snow.

\subsection{Comparison of isotope mixing and the emission model}

Estimates on nitrogen sources - especially diffuse ones are urgently needed to guide management of river catchments. Diffuse nitrogen sources include atmospheric deposition and soil runoff. Geographical information systems like the GLC are widely used tools for such source attribution, but independent tests of their reliability are rare (Deutsch et al., 2006). IMMs are assumed to provide such independent checks on land use data. For the IMM-1 calculation we considered only major nitrate sources, omitting minor ones with shares between $13 \%$ and $0.01 \%$, like surface runoff from urban areas, wetlands or lakes (Table 4, GLC data). We thus distinguished three different major nitrate sources but cannot consider fractionation processes. The GLC-derived proportion of agricultural land and forests agreed reasonably with the IMM-1 data for nitrate from agricultural land and pristine areas, with $r=0.83, n=7, p<0.02$ for the first and $\mathrm{r}=0.76, \mathrm{n}=7, p<0.05$ for the second correlation, respectively. Relative contributions from these three sources according to IMM-1 are shown in Fig. 8a. IMM-1 model has an overall deviation to the GLC estimates of -16 to $+26 \%$ for the rivers with $>50 \% \mathrm{~N}$ from agricultural runoff (Vistula, Oder Peene, Paimionjoki) and deviations between -36 and $+50 \%$ for the three near-pristine ones. The model separates two major groups of rivers - southern rivers and Nordic rivers. In other words $\delta^{15} \mathrm{~N}^{-\mathrm{NO}_{3}^{-}}$of 6-8\% indicates $60-70 \%$ of nitrate from farmland and/or waste water effluents (Table 4 ,
Fig. 8a), which is consistent with the previous comparison of GLC and IMM model data.

The EM model separated the source category fertiliser into mineral fertilizers and sewage/manure and deviations from the IMM- 1 are between -18 and $+18 \%$. The IMM- 2 model calculations, with these two fertiliser types and atmospheric deposition as nitrate sources (Fig. 8b), gave similar shares to the IMM-1. One weakness of the IMM-2 model is that the sum of mineral fertilizer and sewage/manure is close to $100 \%$ (Fig. 9a), which is questionable for Paimionjoki, but fits the estimate of nitrate from farmland and/or STP closely for the Oder, Vistula and Peene. The IMM-2 model therefore seems applicable only to highly fertilized catchments, where a source attribution for different fertilizer types is meaningful.

Model estimates of atmospheric deposition diverge widely for the Nordic rivers and Paimionjoki, but agree better for the other rivers (Fig. 9b). The EM model deviates most from the IMM-2, presumably because it lacks pristine nitrogen. We regard atmospheric deposition estimates from IMM-1 as more reliable, since they compare well with GLC estimates of nitrate emission from farmland and soils hardly affected by human perturbations.

Finally, pristine sources in IMM-1 were compared with the GLC data for forest and wetland/bare/open water (Fig. 9c). Again, the largest deviations were observed for the Nordic rivers, with the same trend of pristine areas dominating the northern catchments. We assume that the IMM-1 estimates for pristine soils correspond mainly to forested areas with some contribution of wetland and open land or lakes. We have discussed this correlation between isotope values and vegetation cover previously. It should be noted that nitrate concentrations in rivers draining pristine, forested areas are below $30 \mu \mathrm{moll}^{-1}$, very low compared to Vistula and Oder.

\section{Conclusions}

IMMs are helpful tools for verifying land use estimates made with other approaches. Careful interpretation is necessary for catchments dominated by nitrate sources not well constrained. Large catchments with little anthropogenic influence like the Kemijoki and the Neva (excepting the city of St. Petersburg) in our study need to be addressed separately. Variations of end members in additional IMM runs, like the IMM-2 in this study, can be useful for differentiating the contributions from different fertilizer types in catchments with a high proportion of farmland. Additional isotope pairs may be useful to differentiate between runoff from farmland and sewage treatment plant effluents. In pristine areas EMs are not useful to apportion sources, unless they explicitly include pristine nitrogen.

Acknowledgements. We thank the many helpful people who sampled rivers around the Baltic Sea, with special thanks to S. Sitek from the Sea Fisheries Institute, Branch in Swinoujscie. Support by 
the "Landesamt für Umwelt und Geologie" in Güstrow (S. Kühn) in sampling the Peene is gratefully acknowledged. I. Liskow coordinated sampling and analyses in the Warnemünde laboratory. This research was part of the SIGNAL (Significance of anthropogenic nitrogen for central Baltic Sea N-cycling) project, which is a part of the EC IMPACT cluster (Anthropogenic impacts on the marine environment), and was supported by the European Commission's Environment and Sustainable Development Programme under contract number EVK3-CT-1999-00020.

Edited by: J. Middelburg

\section{References}

Amberger, A. and Schmidt, H.-L.: Natürliche Isotopengehalte von Nitrat als Indikatoren für dessen Herkunft, Geochim. Cosmochim. Acta, 51, 2699-2705, 1987.

Aravena, R., Evans, M. L., and Cherry, J. A.: Stable isotopes of oxygen and nitrogen in source identification of nitrate from septic systems, Ground Water, 31(2), 180-186, 1993.

Battaglin, W. A., Kendall, C., Chang, C. C. Y., Silva, S. R., and Campbell, D. H.: Chemical and isotopic evidence of nitrogen transformation in the Mississippi River, 1997-98, Hydrol. Progress, 15, 1285-1300, 2001.

Böttcher, J., Strebel, O., Voerkelius, S., and Schmidt, H.-L.: Using isotope fractionation of nitrate-nitrogen and nitrate-oxygen for evaluation of microbial denitrification in a sandy aquifer, $\mathrm{J}$. Hydrol., 114, 413-424, 1990.

Boyer, E. W., Goodale, C. L., Jaworski, N. A., and Howarth, R. W.: Anthropogenic nitrogen sources and relationships to riverine nitrogen export in the northeastern U.S.A., Biogeochemistry, 57/58, 137-169, 2002.

Brandes, J. A. and Devol, A. H.: Isotopic fractionation of oxygen and nitrogen in coastal marine sediments, Geochim. Cosmochim. Acta, 61(9), 1793-1801, 1997.

Burns, D. A. and Kendall, C.: Analysis of ${ }^{15} \mathrm{~N}$ and ${ }^{18} \mathrm{O}$ to differentiate $\mathrm{NO}_{3}^{-}$sources in runoff at two watersheds in the Ctaskill Mountains of New York, Water Resour. Res., 38, 9-1-9-11, 2002.

Chang, C. C. Y., Kendall, C., Silva, S. R., Battaglin, W. A., and Campbell, D. H.: Nitrate stable isotopes: tools for determining nitrate sources among differnt land uses in the Mississippi River Basin, Can. J. Fish. Aquat. Sci., 59, 1874-1885, 2002.

Claesson, S. and Steineck, S.: Växtnäring, hushållning och miljö (in Swedish), Uppsala, 1991.

Deutsch, B., Liskow, I., and Voss, M.: Identification and quantification of diffuse nitrogen inputs into a river system using stable isotopes of oxygen and nitrogen in nitrate, Organic Chemistry, 37, 1333-1342, 2006.

Elmgren, R.: Understanding Human Impact on the Baltic Ecosystem: Changing Views in Recent Decades, Ambio, 30(4-5), 222231, 2001.

FAOSTAT: Agricultural data, FAO, 2005, http://www.fao.org/ waicent/portal/statistics_en.asp, 2005.

Flipse, W. J. and Bonner, F. T.: Nitrogen-Isotope Ratios of Nitrate in Ground Water Under Fertilized Fields, Long Island, New York, Ground Water, 23(1), 59-67, 1985.

Fogg, G. E., Rolstom, D. E., Decker, D. L., Louie, D. T., and Grismer, M. E.: Spatial variation in nitrogen isotope values beneath nitrate contamination sources, Ground Water, 36(3), 418-426, 1998.

Galloway, J. N. and Cowling, E. B.: Reactive Nitrogen and The World: 200 Years of Change, Ambio, 31(2), 64-71, 2002.

Galloway, J. N., Schlesinger, W. H., Il, H. L., Michaels, A., and Schnoor, J. L.: Nitrogen fixation: Antropogenic enhancementenvironmental response, Global Biochem. Cycles, 9(2), 235252, 1995.

Granat, L.: Deposition of nitrate and ammonium from the atmosphere to the Baltic Sea, in: A Systems Analysis of the Baltic Sea, edited by: Wulff, F. V., Rahm, L. A., and Larsson, P., Ecological Studies. Springer-Verlag, Berlin Heidelberg, pp. 133148, 2001.

Granger, J., Sigman, D. M., Needoba, J. A., and Harrison, P. J.: Coupled nitrogen and oxygen isotope fractionation of nitrate during assimilation by cultures of marine phytoplankton, Limmnol. Oceanogr., 49(6), 1763-1773, 2004.

Grasshoff, K., Ehrhardt, M., and Kremling, K.: Methods of Seawater Analysis, Verlag Chemie, 419 pp, 1983.

Grimvall, A. and Stålnacke, P.: Riverine Inputs of nutrients to the Baltic Sea, in: A Systems Analysis of the Baltic Sea, edited by: Wulff, F. V., Rahm, L. A., and Larsson, P., Ecological Studies. Springer-Verlag, Berlin Heidelberg, pp. 113-131, 2001

Grischek, T., Hiscock, K. M., Metschies, T., Dennis, P. F., and Nestler, W.: Factors affecting denitrification during infiltration of river water into a sand and gravel aquifer in Saxony, Germany, Water Res., 32(2), 450-460, 1997.

Harrington, R. R., Kennedy, B. P., Chamberlain, C. P., Blum, J. D., and Folt, C. L.: ${ }^{15} \mathrm{~N}$ enrichment in agricultural catchments: field patterns and applications to tracking Atlantic salmon (Salmo salar), Chemical Geology, 147, 281-294, 1998.

Hastings, M. G., Steig, E. J., and Sigman, D. M.: Seasonal variations in $\mathrm{N}$ and $\mathrm{O}$ isotopes of nitrate in snow at Summit, Greenland: Implications for the study of nitrate in snow and ice cores, J. Geophys. Res., 109(D20306), 1 of 11, doi:10.1029/2004JD004991, 2004.

Heaton, T. H. E.: Isotopic studies of nitrogen pollution in the hydrosphere and atmosphere: A review, Chemical Geology, 59, 87 $102,1986$.

HELCOM: Baltic Sea Environment Proceedings: Environment of the Baltic Sea area 1994-1998, Baltic Sea Environment Proceedings Helsinki Commission, 82B, 215 pp., 2002.

HELCOM: Baltic Sea Environment Proceedings: The Fourth Baltic Sea Pollution Load Compilation, Baltic Sea Environment Proceedings, No 93, Baltic Marine Environment Protection Commission, Helsinki, 2004.

Howarth, R. W., Billen, G., Swaney, D., Townsend, A., Jarowski, N., Lajtha, K., Downing, J. A., Elmgren, R., Caraco, N., Jordan, T., Berendse, F., Freney, J., Kudeyarov, V., Murdoch, P., and Zhao-Liang, Z.: Regional Nitrogen Budegts and riverine N \& P fluxes for the drainage to the North Atlantic Ocean: Natural and human influences, in: Nitrogen cycling in the North Atlantic Ocean and its Watersheds, edited by: Howarth, R. W., Kluwer Academic Publishers, pp. 75-139. 1996.

Humborg, C., Blomqvist, S., Avsan, E., Bergensund, Y., and Smedberg, E.: Hydrological alterations with river damming in northern Sweden: Implications for weathering and river biogeochemistry, Global Biogeochem. Cycles, 16, 3, doi:10.1029/2000GB001369, 12-1-12-13, 2002. 
Humborg, C., Smedberg, E., Blomqvist, S., Mörth, C.-M., Brink, J., Rahm, L., Danielson, A., and Sahlberg, J.: Nutrient variations in boreal and subarctic Swedish rivers: Landscape control of landsea fluxes, Limmnol. Oceanogr., 49(5), 1871-1883, 2004.

Johnes, P., Moss, B., and Phillips, G.: The determination of total nitrogen and total phosphorus concentrations in freshwaters from land use, stock headage and population data: Testing of a model for use in conservation and water quality management, Freshwater Biology, 36, 451-473, 1996.

Kendall, C.: Tracing nitrogen sources and cycling in catchments, in: Isotope Tracers in Catchment Hydrology, edited by: Kendall, C. and McDonnell, J. J., Elsevier, Amsterdam, Lausanne, New York, pp. 519-576, 1998.

Kendall, C., Silva, S. R., and Chang, C. C. Y.: Use of the $\delta^{18} \mathrm{O}$ and $\delta^{15} \mathrm{~N}$ of nitrate to determine sources of nitrate in early spring runoff in forested catchments, Isotopes in Water Resources Management, IAEA, Vienna, pp. 167-176, 1995.

Kendall, C., Silva, S. R., and Kelly, V. J.: Carbon and nitrogen isotopic compositions of particulate organic matter in four large river systems across the United States, Hydrol. Progress, 15, 1301-1346, 2001.

Kuuppo, P., Tamminen, T., Voss, M., and Schulte, U.: Nitrogenous discharges from River Neva and St. Petersburg: elemental flows, stable isotope signatures, and their estuarine modification in the Gulf of Finland, the Baltic Sea., J. Mar. Syst., 63, 191-208, 2006.

Larsson, U., Elmgren, R., and Wulff, F.: Eutrophication and the Baltic Sea: causes and consequences, Ambio, 14, 9-14, 1985.

Mariotti, A., Lancelot, C., and Billen, G.: Natural isotopic composition as a tracer of origin for suspended organic matter in the Scheldt estuary, Geochim. Cosmochim. Acta, 48, 549-555, 1984.

Mayer, B., Bollwerk, S. M., Mansfeldt, T., Hütter, B., and Veizer, J.: The oxygen isotope composition of nitrate generated by nitrification in acid forest floors, Geochim. Cosmochim. Acta, 65(16), 2743-2756, 2001.

Mayer, B., Boyer, E. W., Goodale, C., Jaworski, N. A., Breemen, N. v., Howarth, R. W., Seitzinger, S., Billen, G., Lajtha, K., Nadelhoffer, K., Dam, D. v., Hetling, L. J., Nosal, M., and Paustian, K.: Sources of nitrate in rivers draining sixteen watersheds in the northeastern U.S.: Isotopic constraints, Biogeochemistry, 57/58, 171-197, 2002.

McClelland, J. W. and Valiela, I.: Linking nitrogen in estuarine producers to land-derived sources, Limnology and Oceanography, 43(4), 577-585, 1998.

McClelland, J. W., Valiela, I., and Michener, R. H.: Nitrogen-stable isotope signatures in estuarine food webs: A record of increasing urbanization in coastal watersheds, Limnology and Oceanography, 42(5), 930-937, 1997.
Montoya, J. P. and McCarthy, J. J.: Isotopic fractionation during nitrate uptake by phytoplankton grown in continuous culture, J. Plankton Res., 17, 439-464, 1995.

Nadelhoffer, K. J. and Fry, B.: Nitrogen isotope studies in forest ecosystems, in: Stable isotopes in Ecology and Environmental Science. Methods in Ecology, edited by: Lajtha, K. and Michener, R. H., Blackwell Scientific Publications, Oxford, pp. 2244, 1994.

Nausch, G., Nehring, D., and Aertebjerd, G.: Anthropogenic nutrient load of the Baltic Sea, Limnologica, 29, 233-241, 1999.

Ostrom, N. E., Knoke, K. E., Hedin, L. O., Robertson, G. P., and Smucker, A. J. M.: Temporal trends in nitrogen isotope values of nitrate leaching from agricultural soil, Chem. Geology, 146, 219-227, 1998.

Phillips, D. L. and Koch, P. L.: Incorporating concentration dependence in stable isotope mixing models, Oecologia, 130, 114-125, 2002.

Sebilo, M., Billen, G., Grably, M., and Marotti, A.: Isotopic composition of nitrate-nitrogen as a marker of riparian and benthic denitrification at the scale of the whole Seine River system, Biogeochemistry, 63, 35-51, 2003.

Seitzinger, S., Styles, R. v., Boyer, E. W., Alexander, R. B., Billen, G., Howarth, R. W., Mayer, B., and Breemen, N. v.: Nitrogen retention in rivers: model development and application to watersheds in the northeastern U.S.A., Biogeochemistry, 57/58, 199237, 2002.

Sigman, D. M., Altabet, M. A., Michener, R., McCorkle, D. C., Fry, B., and Holmes, R. M.: Natural abundance-level measurement of the nitrogen isotopic composition of oceanic nitrate: an adaptation of the ammonia diffusion method, Mar. Chem., 57, 227-242, 1997.

Silva, S. R., Kendall, C., Wilkison, D. H., Ziegler, A. C., Chang, C. C. Y., and Avanzino, R. J.: A new method for collection of nitrate from fresh water and analysis of nitrogen and oxygen isotope ratios, J. Hydrol., 228, 22-36, 2000.

Stålnacke, P., Grimvall, A., Sundblad, K., and Tonderski, A.: Estimation of riverine loads of nitrogen and phosphorous to the Baltic Sea, 1970-1993, Environ. Monitor. Assess., 58, 173-200, 1999.

UNESCO: Chemical methods for the use in marine environmental monitoring., Manual and guides, Intergovernmental Oceanographic Commission, 12, 1-53, 1983.

Voss, M., Emeis, K.-C., Hille, S., Neumann, T., and Dippner, J. W.: The nitrogen cycle of the Baltic Sea from an isotopic perspective, Global Biochem. Cycles, 19, 1-16, doi:10.1029/2004GB002338, 2005.

World Meteorological Organization: Guide to Hydrological Practices, WMO-No 168, World Meteorological Organization, Report No 168, 1994. 